\title{
Online vs. offline: axiological model of educational Rhizoma-like professional spaces
}

\author{
Nadezhda Bulankina ${ }^{1 *}$, Natalya Malakhova ${ }^{2}$, and Olga Mishutina ${ }^{2}$ \\ ${ }^{1}$ Novosibirsk Institute of Professional Skills Improvement and Vocational Retraining of Education \\ Workers, 630007, Novosibirsk, Russia \\ ${ }^{2}$ Novosibirsk State Pedagogical University, 630126, Novosibirsk, Russia
}

\begin{abstract}
It is curious to reflect that so much significance has been given to Tutoring for teachers within the period of COVID-19 pandemic in the spaces of some destructive changes of the postmodernism educational paradigm. Both the behaviorist/structural model and functional /communicative model have, in their different ways and aspects, consistently played it in terms of the emphasis on correspondence, on-line and off-line courses. This study suggests some ways of opening up daily situations and cases with ICT means for learners in the regional professional spaces of modern language teaching in terms of axiological approach that considers student-centered techniques as a priority a) to establish the psychological balance in the classroom, which is essential for security and stability of the communicative environment and educational process for each participant; b) to fill the gap in different sections of Grammar and Vocabulary for any learner; c) to open up the possibilities for both gifted children and children/adults with special needs.
\end{abstract}

\section{Introduction}

Problem statement. Researchers recognized a concept "innovations" as key factors for productivity, growth and regional development [1]. The continuity of conceptual knowledge between all the levels of educational system necessarily acquired through purposeful and reflective learning. Requirements by the Federal State Educational Standards of the Russian Federation to each level of school/university curricular provide a frame of how an educational space needs to be organized by the educational institutions and teachers. There are substantially differences concerning to extend and uptake of online study formats around the world [2].

Based on pedagogical principles of understanding the school and university educational practices via axiological approach to face-to-face activities and communication online [3, 4], student and teacher's identity in digitalization processes may be realizing through their engagement in online learning and design of digital environment [5]. As is the case, such issues burden both on the student extra difficulties and on the teacher professional deficits, but the appropriate indicators of his/her knowledge are steadily rising. The indicators or metrics for measuring the relevance of knowledge had ranged into three groups: a) ICT

\footnotetext{
*Corresponding author: nebn@yandex.ru
} 
knowledge; b) conceptual knowledge; c) awareness of innovations in the region. Each group of metrics connecting with the other two types of knowledge, and in complex, they give effective pedagogical ideas to a teacher. For instance, such indicators are useful to practice some techniques for uniting students at classes into cohesive teams, or dividing them into several micro groups according to the necessity.

The purpose of this study is to reflect on the pivotal ideological trends of the longitudinal research (2016-2020) on the innovations within the rhizome-like educational professional spaces at Novosibirsk Destination, public school institutions, i.e. vocational training environment of a university, as well as professional skills improvement system, carried out in the Novosibirsk Region through the collaboration of the Foreign Languages Department at Novosibirsk State Pedagogical University (NSPU) and the Department of International Languages Education at Novosibirsk Institute of Professional Skills Improvement \& Vocational Retraining of Education Workers.

\section{Materials and Methods}

Current scientific Scholarship highlights a spectrum of high-technology industries, and "the smartphone industry integrated cell phones, portable computers, and software; the nutraceutical and functional food industry, which was created through convergence between the pharmaceutical and food industries, etc." [6]. These peculiarities of the likely ideological trends do not relate only to the industrial sector, but in the main to methodological approaches to education $[7,8]$. "The formation of communicative personality, aspiration to development priorities and dominant convergent things should stimulate modern teachers to learn different assets of the subject's content, to discuss them together with the students, and to take into consideration their ideas and opinions concerning instructional enhancements in the traditional classroom" [9]. Education is one of the core drivers of innovations development in any region, because the well-educated personnel has competitive position among other employees. Moreover, one of the main characteristics of recurrent education is active introduction and use of information distance technologies to organize educational activities $[10,11,12]$.

English as a Foreign Language is an integrative academic discipline in school and university curricular, intended to stimulate the students to get to know with a wide range of language tools for understanding, analyzing, and studying the world around. The term "EFL" firstly used in 1985, referred to the type of spread, and the functional allocation of the English language in three circles: Inner, Outer, and Expanding ones. The Russian Federation relates by researchers to the Expanding Circle (B. Kachru, 1985; Sh. Isani, 2014) [13]. At the same time, "English in the Outer Circle should be valid in terms of the following: the sociolinguistic contexts, the functional contexts, the pragmatic contexts, and the attitudinal contexts" [14]. All these four contexts from the Outer Circle are suitable in teaching English for Specific Purposes in Expanding Circle countries. Conventional educational studies focusing on teaching towards a research-orientated interest consider ESP as an essential means for appropriate understanding what the world of professional discourse is like.

Nowadays, the issue of pedagogical support for the teachers is rather important in many countries, than it was during the 2000-2010s (Mike Taylor, et al., 2011), when "a variety of strategies to deliver the professional development, including workshops, short courses, oneto-one tutorials, mentoring, professional reading, classroom visits, and email support" [15] had been used as a common practice. In 2020-s, practical support would be based within digital educational space. For instance, different strategies as BYOD (bring your own device), MALL (mobile assisted language learning), CALL (computer assisted language learning) issues become necessary because of sharing readily available ICT. In 2017, Song Y., Kong S.Ch. make clear the seven types of affordances of Bring Your Own Device 
(BYOD) for the wide range of learning activities: "resource access tool, communication tool, resource collection tool, resource submission tool, knowledge construction tool, resource sharing tool, and representation tool" [16]. During this research at NSPU and Novosibirsk Teachers' Upgrading and Retraining Institute, the attention has been given to communicatively directed pedagogical practices [17], and the communication tool, as well as to the resource collection ones.

\section{Results and Their Discussion}

Novosibirsk Institute of Professional Skills Improvement \& Vocational Retraining of Education Workers designed special modules of the pedagogical support and included them into the Curricular of Correspondence Courses for teachers of foreign languages. There are different modules in an average course structure: M-1: Grammar Review - the first module has been arranged into three levels according to the Common European Framework of Reference for Languages (Basic, Independent, and Proficient User); M-2: Language of Innovations in the Novosibirsk Region - provides resources for teaching the English language for Specific Purposes (Natural Sciences, IT, etc.), especially for gifted children; M-3: Essential Thesaurus for Special Needs - this module including the set of core methods for carrying out the peculiarities of a teacher's work for students with special needs.

The most relevant resources and tasks in all three modules directed to the pedagogical support for a teacher. In Module 1, digital documents and files (i.e. a diverse variety of pictures, photos, emergency signs, schemes, diagrams, phonetic charts, etc.) arranged by their accessibility, reliability, trustworthiness, and external links. According to the research results, $87 \%$ of teachers noted the usefulness and practical value of this module. $72 \%$ of participants found out the importance of Module 2, which was included into the Correspondence Courses. We can suggest, this result relates to the level of high difficulty and directness of these materials for special school/lyceum/gymnasium with in-depth subject information on foreign languages or Natural Sciences. Module 3 had been studied with much diligence by $96 \%$ of teachers. They passed out a short questionnaire devoted to some issues of classroom management system and teaching practices for children with special needs, etc.

This paper reports on the research results obtained from the 5-years study. It embraced a series of Correspondence Courses, and in total involved 132 teachers of English as a Foreign Language from the Novosibirsk Region. Ages of the participants ranged from 26 to 72 years old. Their work experience was from 1 to 45 years of teaching English as a Foreign Language at schools. The Dominant Value Model covers three frameworks of a) the Information and Communication Technologies (ICT) that correlate with the necessity of implementing newly methodological approaches to the teaching and learning process, and pedagogical support for educators; b) the acculturation of the professional spaces of physics, biology and chemistry in the Russian Science segment that contributes to the development of medicine, pharmaceuticals, biochemistry, living systems, genetics, molecular biology, biotechnology, etc; c) indicators of evaluation of Pedagogy and Knowledge Content Efficacy of the professional programmes for the students interested in Natural Sciences, Modern International Languages, and lots of web resources, blogs, papers, in the aspect of a rhizomatic personal learning environment.

Pedagogical design of the Refresher Correspondence Courses based on Moodle platform including links to Web $1.0 \& 2.0$ resources. The key tools of the syllabus relate to a rhizomatic personal learning environment, the placement/final tests assessment, and the feedback. The participants have studied video/audio/image content personally. A set of questions in placement/final tests is used to measure the level of English language proficiency according to the CEFR as international language standards scale. 
Feedback from the target users (courses' participants) is very constructive, and indicates the teachers' interest in improving their four communicative skills (listening, speaking, reading, and writing) (see Fig. 1).

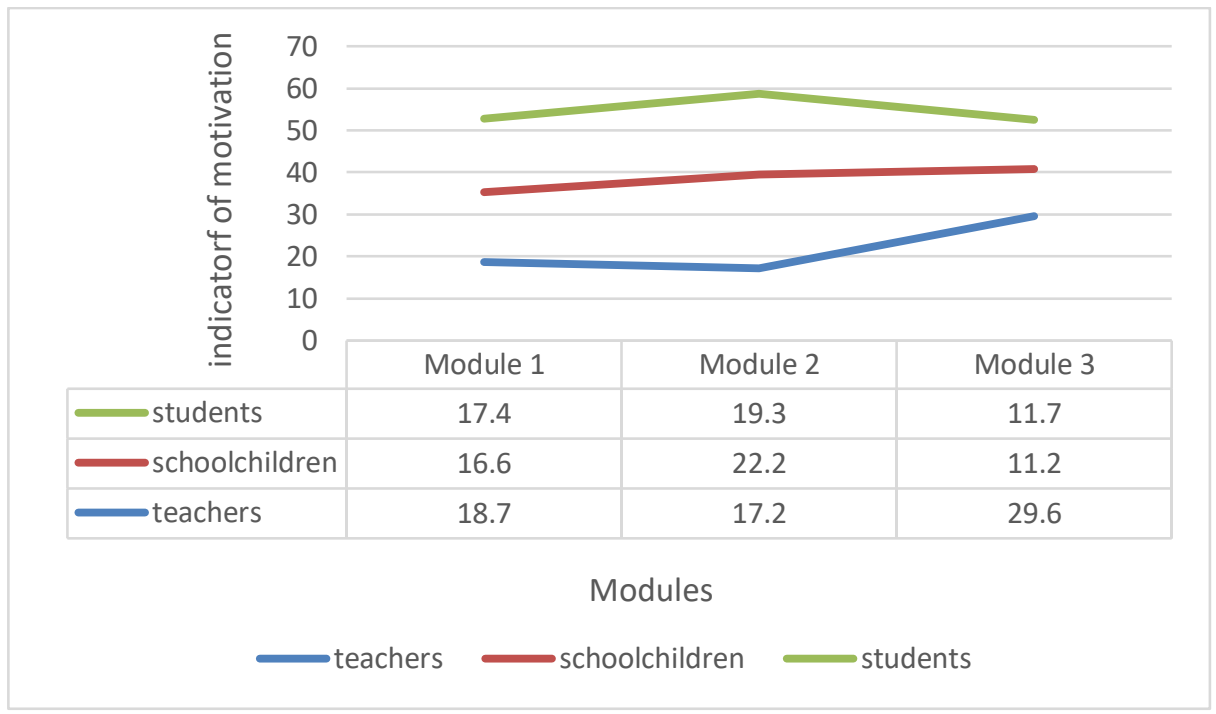

Fig. 1. Teachers', schoolchildren' and students' engagement into effective integration via quick check tasks from the special modules.

Moreover, it is found out a teacher's readiness for substantive acceptance of new pedagogical technologies in TEFL (for achieving a full student participation into group work by means of co-working classroom management), and forward-looking competencies to organize the educational space via the teachers' work with special resources of Modules $2 \&$ 3 .

\section{Conclusions}

Videoconferencing is considered as a tool for improving communication quality between students and teachers, and can be used as a starting point for designing a standard lecture into the conversation. "The videos and pictures are used as tools for prompting verbal responses. By contrast, in digital storytelling it is the stories themselves that are the main vehicle for constructing, presenting and disseminating knowledge: they are stand-alone objects that capture and document practice, views and experiences from the perspectives of the storytellers" [18].

The role of tutoring practices in the light of the development of value orientations of young people in the context of the leading principles of humanization and cultural selfdetermination of the individual in the multilingual educational space is a priority. The understanding of the support landscape has included the frame of CEFR (Module 1) with two equal parts of Language of Innovations in the Novosibirsk Region (Module 2) \& Essential Methodological Thesaurus for Special Needs (Module 3). In all three modules the pedagogical support provides a continual track, and does not stop with the completing of Refresher Courses.

\section{References}


1. L. Polverary, European Policy Research Paper. University of Strathclyde Publishing, UK 102, (2018)

2. C.E. Tomte, et al., Quality in Higher Education 25(1), 98-114 (2019) doi:org/10.1080/13538322.2019.1603611 - last accessed: 18.02.2021.

3. N. Severova, Developing Collaboration Skills through Extracurricular Project Working in German Language Learning as a Non-Linguistic Faculty, In: (EDULEARN17), Proceedings. 9th International Conference on Education and New Learning Technologies, Barcelona, Spain, 10489-10493 (2017) doi:org/10.21125/edulearn.2017.0989 - last accessed: 24.02.2021.

4. S. Hrastinski, Interactive Learning Environments doi:org/10.1080/10494820.2019.1594959 - last accessed: 14.03.2021.

5. I. Engeness, European Journal of Teacher Education 44(1), 96-114 (2021) doi:org/10.1080/02619768.2020.1849129 - last accessed: 08.02.2021.

6. Hyeokseong Lee, et al., Sustainability 8, 1029 (2016) doi:org/10.3390/su8101029 - last accessed 05.02.2021.

7. W. Bowen, Higher Education in a Digital Age (2nd edn. Princeton University Press, USA, 2013).

8. N. Malakhova, et al., International Journal of Applied Exercise Physiology, Kemerovo, Russian Federation 8(2.1), 698-709 (2019)

9. O. Mishutina, Siberian Teacher 5(114), 5-11 (2017)

10. T. Lopatukhina, et al., Foreign Language Professionally-Oriented Training Students of Technical Universities in the System of Recurrent and Lifelong Education, In: (INTED2020) Proceedings, 14th International Technology, Education and Development, Spain, 7413-7419 (2020). doi: 10.21125/inted.2020.1984 - last accessed: 10.03.2021.

11. T. Lopatukhina, et al., Personalized Education: Origins, Characteristics and Technology of Use, In: (EDULEARN20) Proceedings, 12th International Conference on Education and New Learning Technologies, Spain: Palma de Mallorca, 899-904 (2020) doi: 10.21125/edulearn.2020.0315 - last accessed: 4.03.2021.

12. A. Toth, European Academic Research 1(11), 4771-4794 (2014)

13. I. Shaeda, Asp 66, 27-39, (2014) doi: 10.4000/asp.4531 - last accessed: 07.02.2021.

14. B. Kachru, World Englishes and Applied Linguistics, In: Tickoo, Makhan L., Ed. (Languages \& Standards: Issues, Attitudes, Case Studies. Florida, USA, 1991)

15. M. Taylor, et al., An International Journal of Research and Studies 27(1), 85-94 (2011) doi.org/10.1016/j.tate.2010.07.005 - last accessed 14.03.2021.

16. Y. Song, et al., Retracted Chapter: "Affordances and Constraints of BYOD (Bring Your Own Device) for Learning in Higher Education: Teachers' Perspectives", In: Kong S., Wong T., Yang M., Chow C., Tse K. (eds.). Emerging Practices in Scholarship of Learning and Teaching in a Digital Era. Springer, Singapore 105-122 (2017) doi.org/10.1007/978-981-10-3344-5_7 - last accessed 05.02.2021.

17. N. Bulankina, Scientifical and Practical Journal. Irkutsk, Russian Federation 3, 442-451 (2019)

18. S. Parsons, et al., International Journal of research \& Method in Education 38(3), 247 271 (2015) doi.org/10.1080/1743727X.2015.1019852 - last accessed: 20.02.2021. 